\title{
EXAMPLE AND NON-EXAMPLE LEARNING MODEL BERBANTUAN MEDIA POSTER UNTUK MENUMBUHKAN KEMAMPUAN KONEKSI MATEMATIS MAHASISWA
}

\author{
Wanda Nugroho Yanuarto ${ }^{1}$, Eka Setyaningsih ${ }^{2}$ \\ ${ }^{1,2}$ Program Studi Pendidikan Matematika, FKIP Universitas Muhammadiyah Purwokerto \\ e-mail: ${ }^{1}$ wandanugroho86@gmail.com ; ${ }^{2}$ eka.ning@yahoo.com
}

\begin{abstract}
Abstrak
Proses belajar matematika yang dilakukan di program studi Pendidikan Matematika, Universitas Muhammadiyah Purwokerto, hendaknya mendukung kemampuan mahasiswa untuk mencari konsep dari belajar itu sendiri sebagai proses belajar mereka. Untuk menciptakan suasana belajar dimana mahasiswa dapat mencari ide dan konsep belajar matematika mereka sendiri perlu didukung oleh model pembelajaran yang dapat efektif untuk menyelesaikan masalah tersebut dan media pembelajaran guna alat bantu mahasiswa untuk memaksimalkan kemampuan matematika mereka. Penggunaan Example and Non-Example Learning Model dengan berbantuan media pemelajaran poster diharapkan dapat merubah kondisi belajar yang pasif menjadi aktif dan kreatif, menumbuhkembangkan kemampuan dalam pembelajaran secara umum, dan menciptakan kemampuan matematika secara khusus, seperti kemampuan koneksi matematika, serta mengubah pembelajaran yang teacher oriented ke student oriented. Oleh karena itu, dengan menggunakan Pembelajaran Example and Non-Example berbantuan media pembelajaran poster secara berulang-ulang di mata kuliah Teori Belajar dan Pembelajaran program studi Pendidikan Matematika Universitas Muhammadiyah Purwokerto diharapkan dapat menumbuhkan kemampuan koneksi matematika mahasiswa.
\end{abstract}

Kata Kunci : example and non-example, media pembelajaran poster, dan kemampuan koneksi matematis

\section{PENDAHULUAN}

Pembelajaran matematika hendaknya diarahkan agar mahasiswa mampu secara mandiri menyelesaikan masalah-masalah matematika ataupun masalah-masalah yang lain yang diselesaikan dengan bantuan matematika. Untuk lebih meningkatkan kemampuan diri sebagai pengajar profesional, mahasiswa perlu mengetahui teori belajar yang dikemukakan beberapa ahli pendidikan dan aplikasinya dalam pembelajaran matematika.

Tidak hanya tingkat kedalaman konsep yang diberikan kepada mahasiswa tetapi harus disesuaikan dengan tingkat kemampuannya, cara penyampaian materi pun demikian pula. 
Dosen harus mengetahui tingkat perkembangan mental mahasiswa dan bagaimana pengajaran yang harus dilakukan sesuai dengan tahap-tahap perkembangan tersebut. Pembelajaran yang tidak memperhatikan tahap perkembangan mental mahasiswa besar kemungkinan akan mengakibatkan mahasiswa mengalami kesulitan, karena apa yang disajikan tidak sesuai dengan kemampuan dalam menyerap materi yang diberikan.

Pada mata kuliah Teori Belajar dan Pembelajaran yang disajikan untuk mahasiswa semester 2 Pendidikan Matematika Universitas Muhammadiyah Purwokerto memiliki berbagai kendala yang dihadapi. Kendala tersebut sudah dialami oleh dosen pada semester 1 . Mahasiswa dengan tingkat kematangan mental belum cukup untuk memenuhi kebutuhan belajarnya di tingkat perguruan tinggi juga belum mengetahui betul bagaimana cara belajar yang efektif guna meningkatkan kemampuan akademik dan sosial mereka. Berbagai masalah yang dihadapi diantaranya: 1) mahasiswa belum bisa menggunakan kemampuan mengkoneksikan ide dan gagasan dari berbagai sumber belajar yang ada; 2) proses pembelajaran di kelas yang masih pasif, sehingga mahasiswa belum mampu untuk memaksimalkan kemampuan matematika mereka; dan 3) pembelajaran yang bersifat abstrak dan tidak menyentuh ke aplikasi kehidupan nyata membuat mahasiswa kesulitan untuk menghubungkan konsep dan aplikasi pada situasi nyata.

Dari permasalahan yang dihadapi oleh dosen pengampu mata kuliah Teori Belajar dan Pembelajaran tersebut, dibuatlah suatu rancangan pembelajaran yang dapat mengakomodir semua permasalahan yang ada. Solusi yang ada begitu menjadi pokok penting dalam pembelajaran di kelas, karena pengetahuan tentang teori belajar dalam sistem penyampaiaan materi dalam kelas penting, sehingga setiap model pengajaran harus selalu disesuaikan dengan teori-teori belajar yang dikemukakan oleh ahli pendidikan. Beberapa teori belajar psikologi diaplikasikan dalam pendidikan, dan diungkapkan bagaimana implikasinya dalam pembelajaran matematika.

Di dalam proses belajar, Bruner mementingkan keaktifan dari tiap mahasiswa, dan mengenal dengan baik adanya perbedaan kemampuan. Untuk menunjang proses belajar perlu lingkungan memfasilitasi kemampuan setiap individu mahasiswa pada tahap eksplorasi. Lingkungan ini dapat tercover pada Example and Non-Example Learning Model, yaitu sebuah pembelajaran dimana mahasiswa dapat melakukan eksplorasi, penemuan-penemuan baru yang belum dikenal, dan menganalisa sejauhmana keterkaitan teori belajar dengan pembelajaran matematika secara khusus. Lingkungan seperti ini bertujuan agar mahasiswa dalam proses belajar dapat berjalan dengan baik dan lebih efektif.

Proses belajar matematika yang dilakukan di program studi Pendidikan Matematika, Universitas Muhammadiyah Purwokerto, hendaknya mendukung kemampuan mahasiswa untuk mencari konsep dari belajar itu sendiri sebagai proses belajar mereka. Untuk menciptakan suasana belajar dimana mahasiswa dapat mencari ide dan konsep belajar matematika mereka sendiri perlu didukung oleh model pembelajaran yang dapat efektif untuk menyelesaikan masalah tersebut dan media pembelajaran guna alat bantu mahasiswa untuk memaksimalkan kemampuan matematika mereka. 
Example and Non-Example Learning Model merupakan model pembelajaran yang menggunakan gambar sebagai media pembelajaran yang bertujuan mendorong siswa untuk belajar berfikir kritis dengan jalan memecahkan permasalahan-permasalahan yang terkandung dalam contoh-contoh gambar yang disajikan.

Proses berpikir kritis di sini diartikan sebagai suatu proses bagaimana mahasiswa dapat mengoneksikan konsep teori belajar dengan pengaplikasiannya dalam pembelajaran matematika secara khusus. Untuk menumbuhkan kemampuan koneksi matematika tersebut, perlu beberapa bantuan guna mendukung terciptanya kemampuan koneksi yang baik, diantaranya dengan menggunakan Example and Non-Example Learning Model yang tersaji dengan menerapkan beberapa contoh konsep belajar yang sesuai dengan pembelajaran matematika, dan memberikan gambaran yang jelas pula, bagaimana teori belajar tersebut dapat sesuai dengan pembelajaran yang lain. Alat pendukung lain adalah media pembelajaran berupa poster yang di dalamnya berisi contoh-contoh yang diperlukan dalam pembelajaran matematika dan sesuai pula dengan teori belajar yang ada.

Kedua alat bantu tersebut diharapkan dapat menjadi jembatan untuk mahasiswa mengoneksikan proses pembelajaran yang sesuai dengan teori belajar yang ada dan diaplikasikan ke dalam pembelajaran matematika secara khusus. Penggunaan Example and Non-Example Learning Model dengan berbantuan media pemelajaran poster diharapkan dapat merubah kondisi belajar yang pasif menjadi aktif dan kreatif, menumbuhkembangkan kemampuan dalam pembelajaran secara umum, dan menciptakan kemampuan matematika secara khusus, seperti kemampuan koneksi matematika, serta mengubah pembelajaran yang teacher oriented ke student oriented. Oleh karena itu, dengan menggunakan Pembelajaran Example and Non-Example berbantuan media pembelajaran poster secara berulang-ulang di mata kuliah Teori Belajar dan Pembelajaran program studi Pendidikan Matematika Universitas Muhammadiyah Purwokerto diharapkan dapat menumbuhkan kemampuan koneksi matematika mahasiswa.

\section{METODE}

Penelitian yang dilakukan adalah penelitian kualitatif dengan didasarkan atas hasil observasi, wawancara, dan catatan lapangan terkait gejala yang sedang diamati. Proses pelaksanaan penelitian dimulai dengan analisis situasi, dimana siswa yang merasa kesulitan proses menghitung cepat di kelas. Proses selanjutnya adalah tahap persiapan, pada tahap ini dimulai dengan memilih strategi yang tepat untuk menyelesaikan masalah siswa terkait kesulitan tersebut. Untuk mengantisipasi hal tersebut, salah satu alternatif penyelesaiannya adalah dengan menggunakan model pembelajaran example and non-example. Tahap ketiga, adalah pengaplikasian. Tahap pengaplikasian example and non example learning model dengan berbantuan media pembelajaran poster dimulai di kelas kecil dengan melibatkan 5 mahasiswa. Hal ini dilakukan untuk menguji coba apakah model yang diterapkan sudah sesuai dengan tujuan penelitian yang diharapkan. Langkah selanjutnya adalah pelibatan mahasiswa dalam kelas yang lebih besar agar tujuan yang telah ditetapkan dapat terselesaikan 
secara efektif. Subjek penelitian kali ini adalah mahasiswa semester II pada mata kuliah Teori Belajar dan Pembelajaran Universitas Muhammadiyah Purwokerto dengan pelaksanaan pada bulan Mei - Juli 2016.

\section{HASIL DAN PEMBAHASAN}

Example and Non-Example Learning Model Berbantuan Media Poster pada Mata Kuliah Teori Belajar dan Pembelajaran

Teori Belajar dan Pembelajaran dalam mata kuliah yang disajikan di program studi Pendidikan Matematika Universitas Muhammadiyah Purwokerto terdiri dari teori-teori belajar yang terkait dalam pembelajaran matematika yaitu sebagai berikut:

1. Teori behavioristik, meliputi teori Thorndike, teori Watson, teori Clarck Hull, dan teori Edwin Guthrie

2. Teori pengkondisian klasik, seperti teori Pavlov, dan teori Gestalt

3. Teori belajar proses, meliputi teori Skinner, dan teori Gagne

4. Teori kognitif, yaitu teori Bruner, dan teori Piaget

5. Teori belajar geometri, seperti teori Dienes, dan teori Van Hiele

Teori-teori belajar di atas menjelaskan apa itu belajar dan bagaimana belajar itu terjadi. Teori Behavioristik merupakan teori yang menyatakan bahwa belajar adalah perubahan dalam tingkah laku sebagai akibat dari interaksi antar stimulus dan respon. Teori Pengkondisian Klasik menyatakan bahwa belajar merupakan suatu usaha dari organisme untuk mengaitkan atau mengasosiasikan stimulus yang pada akhirnya menghasilkan sustu respon. Teori Gestalt lebih menekankan belajar adalah kecenderungan mempersepsikan apa yang terlihat dari lingkungannya sebagai kesatuan yang utuh. Inti dari Teori Skinner adalah dimana konsekunsi prilaku akan menyebabkan perubahan dalam probabilitas prilaku itu akan terjadi.

Rudi susilana dan Cepi Riana (2009: 14) menjelaskan bahwa poster yaitu sajian kombinasi visual yang jelas, menyolok, dan menarik dengan maksud untuk menarik perhatian orang yang lewat. Berdasarkan pendapat di atas, dapat peneliti simpulkan bahwa media poster secara umum adalah suatu pesan tertulis baik itu berupa gambar maupun tulisan yang ditujukan untuk menarik perhatian banyak orang sehingga pesan yang disampaikan dapat diterima orang lain dengan mudah.

Secara umum poster memiliki kegunaan, yaitu sebagai berikut: (1) memotivasi siswa, poster dalam pembelajaran sebagai pendorong atau memotivasi belajar siswa; (2) peringatan, berisi tentang peringatan-peringatan terhadap suatu pelaksanaan aturan hukum, sekolah, atau sosial, kesehatan bahkan keagamaan; (3) pengalaman kreatif, melalui poster kegiatan menjadi lebih kreatif untuk membuat ide, cerita, karangan dari sebuah poster yang dipajang (Nana Sudjana dan Ahmad Rivai, 2010: 56-57).

Pembelajaran Teori Belajar dan Pembelajaran dapat dimaksimalkan dengan berbagai pendekatan atau model yang dapat diaplikasikan untuk menumbuhkan kemampuan koneksi matematis mahasiswa. Untuk menumbuhkan kemampuan tersebut perlu alat mencapainya. 
Salah satu alat yang dapat dilakukan adalah dengan model pembelajaran Example and NonExample dengan berbantuan media poster. Beberapa tahapan yang harus dilakukan pada penelitian ini adalah sebagai berikut:

\section{Planning}

Pada tahap ini dosen selaku fasilitator memberikan rambu-rambu serta apa saja yang harus dipersiapkan mahasiswa dalam pembelajaran. Langkah-langkah yang harus dipersiapkan mahasiswa pada pembelajaran example and non-example adalah sebagai berikut:

a. Mahasiswa harus membuat kerangka pembelajaran dalam bentuk power point, makalah, dan poster

b. Power point digunakan sebagai media dalam menjelaskan konsep tentang pembelajaran yang akan dilaksanakan. Di dalam power point dijelaskan tentang garis besar teori belajar yang ada

c. Makalah pembelajaran adalah keseluruhan konsep yang dipelajari. Mahasiswa membuat makalah tersebut sebagai acuan dan rambu konsep pembelajaran yang ingin ditransfer.

d. Poster, adalah media tambahan untuk mahasiswa menerangkan aplikasi teori belajar yang ada ke dalam pendidikan secara umum dan pendidikan matematika secara khusus. Proses pembelajaran example and non-example juga tercermin dalam poster tersebut, dimana mahasiswa harus mampu menjelaskan contoh aplikasi teori belajar ke dalam pendidikan matematika, dan mampu menjelaskan tentang bukan contoh (non-example) mengenai aplikasi pembelajaran yang salah.

e. Ketiga perangkat tersebut terlebih dahulu direview dan dilakukan proses bimbingan dengan dosen pengampu mata kuliah agar apa yang nanti disampaikan sesuai dan memiliki persepsi konsep yang sama dengan apa yang dikehendaki oleh dosen dalam rancangan pembelajarannya.

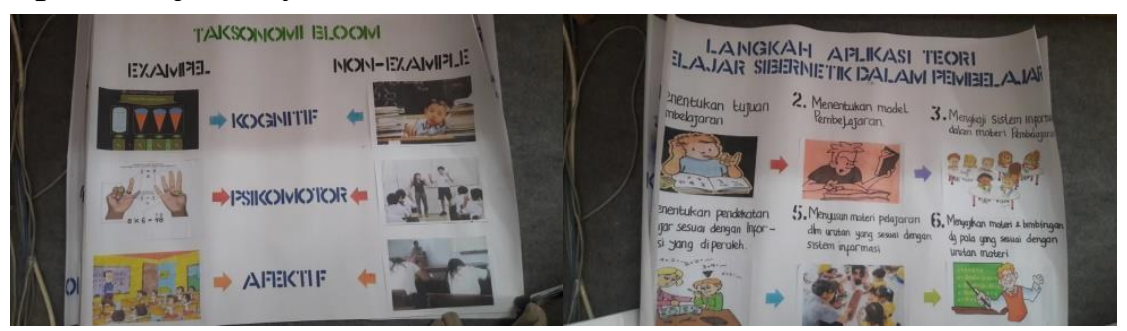

Gambar 1. Contoh media poster yang dibuat mahasiswa dalam pembelajaran

\section{Giving Pictures (Example and Non-Example)}

Tahap penyajian materi di sini sesuai dengan pembelajaran example and non-example adalah mahasiswa dapat memberikan contoh dan bukan contoh dari konsep yang sedang dipelajari melalui gambar. Dalam hal ini gambar dapat direpresentasikan ke dalam media poster. Pembuatan dan penyiapan media poster sudah dilakukan pada tahap persiapan, pada tahap selanjutnya adalah tahapan dimana mahasiswa dapat menjelaskan dari media poster yang telah dibuat. Tujuan dari giving picture ini adalah mahasiswa dapat menunjukkan konsep yang benar dan dapat menjelaskan pula konsep yang salah dari sebuah teori belajar. 
Diharapkan dari kedua hal tersebut, dosen dapat menilai sejauh mana mahasiswa dapat menguasai materi yang disampaikan dan memiliki kemampuan mengkoneksikan sebuah konsep teori belajar secara umum ke dalam proses pembelajaran matematika secara khusus.
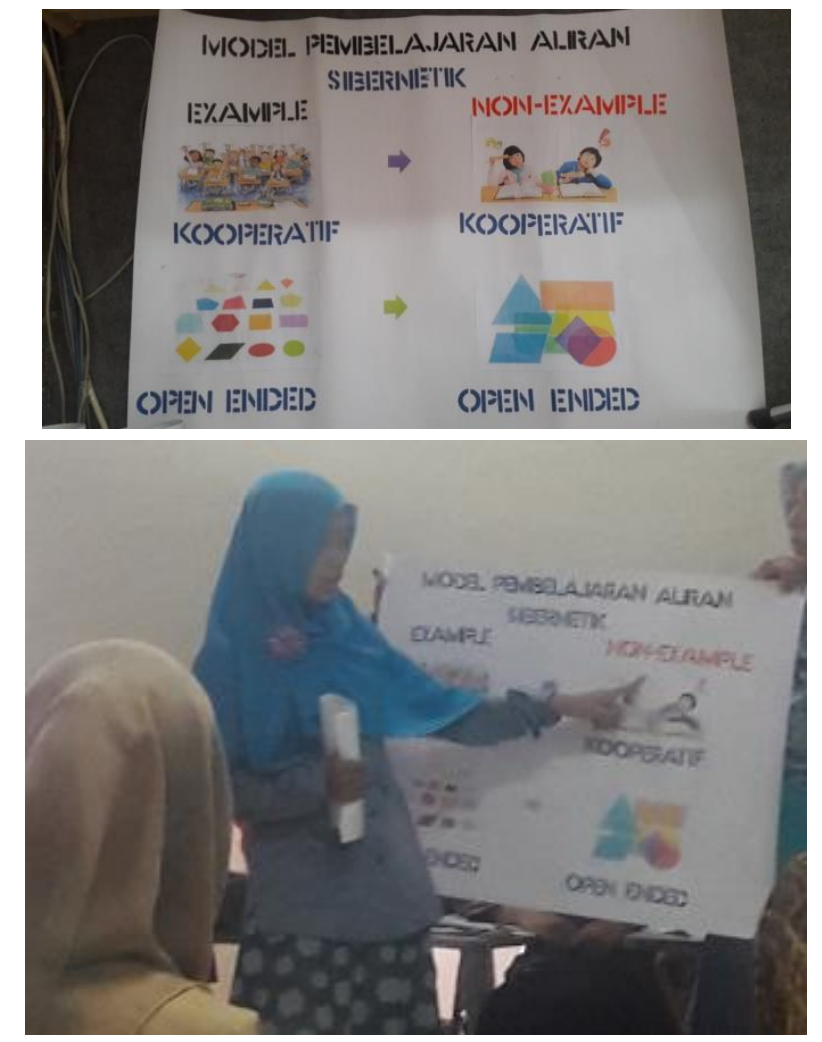

Gambar 2. Mahasiswa memberikan penjelasan konsep yang disajikan dalam sebuah gambar poster

\section{Analyzing Pictures}

Pada tahap ini diharapkan tujuan dari giving picture adalah mahasiswa dapat memberikan analisa mereka terhadap gambar poster yang diberikan. Analisa tersebut dapat terlihat dari apa yang disajikan ke dalam poster tersebut, konsep teori belajar secara umum dapat dikoneksikan ke dalam sebuah media gambar, gambar tersebut berisi analisa konsep teori belajar yang kemudian diaplikasikan ke dalam pendidikan matematika. Analisa yang dilakukan juga untuk mencari konsep yang benar (example) serta mencari konsep yang salah (non-example). Hal ini dilakukan agar siswa dapat mengetahui dengan sebaik-baiknya konsep yang ditransfer ke teman-temannya.

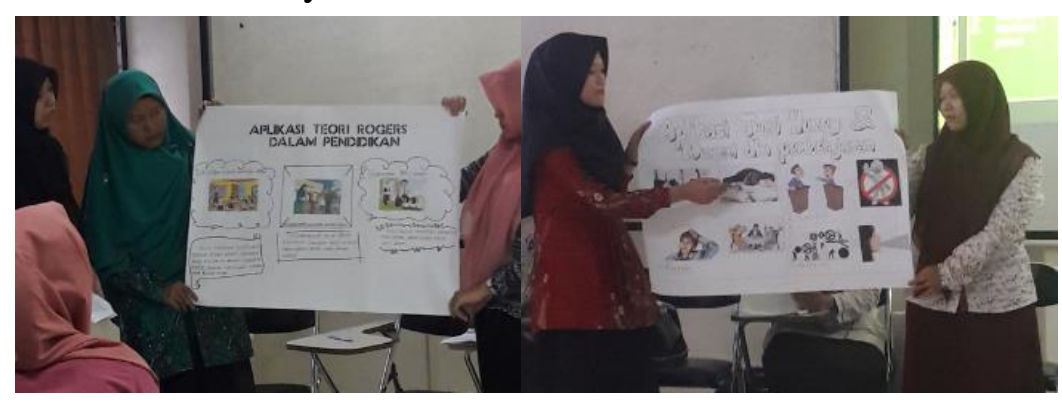

Gambar 3. Mahasiswa menganalisa gambar poster

\section{Discussion}


Proses diskusi dapat dilakukan selama proses berkelompok dengan teman-temannya ataupun pada saat proses presentasi. Hal ini dilakukan agar dalam setiap kegiatan pembelajaran, siswa dapat mengutarakan pendapatnya dan dapat menumbuhkan karakter menghargai pendapat orang lain. Diskusi yang dilakukan juga untuk mencari tahu penyelesaian masalah pada pembelajaran yang tersaji pada setiap tugas yang diberikan dosen.

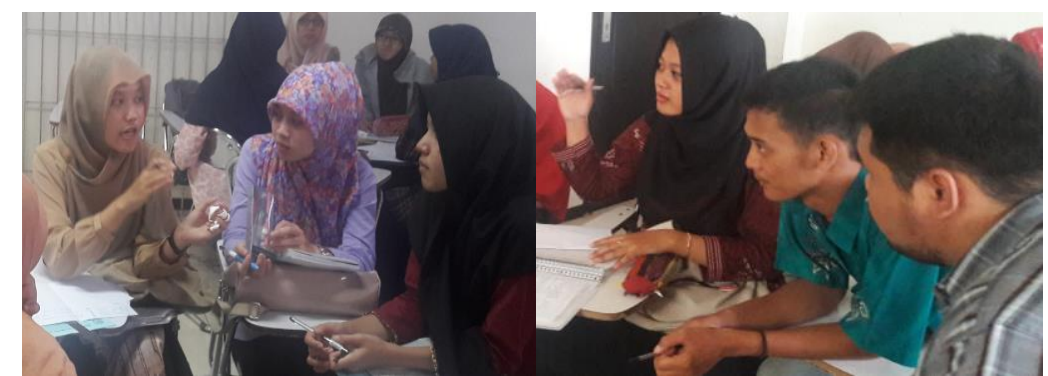

Gambar 4. Mahasiswa berdiskusi bersama kelompoknya

\section{Presentation}

Setiap kelompok mendapat tugas untuk mempresentasikan hasil diskusi mereka dan juga menjelaskan konsep yang mereka temukan. Hal ini dilakukan untuk merangsang kemandirian siswa dan juga kemampuan mengelola informasi. Pada setiap presentasi yang diberikan, setiap kelompok wajib menyiapkan berkas presentasi yang tersaji pada makalah dan power point serta dapat menjelaskan konsep tersebut dalam poster. Hal ini dilakukan untuk dapat memberikan gambaran seluas-luasnya mengenai konsep yang diberikan.

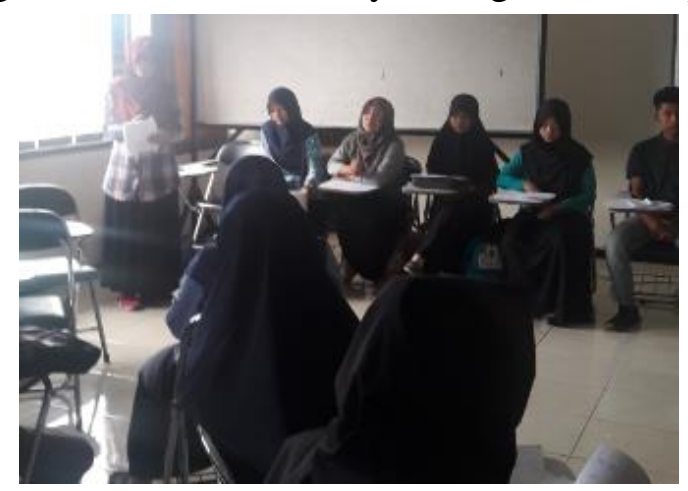

\section{Feedback}

Gambar 5. Kegiatan Presentasi yang dilakukan setiap kelompok

Tahapan ini dilakukan untuk mencari persepsi sama terhadap materi yang sedang diajarkan hari ini. Feedback juga berisi tentang penanaman konsep yang benar dilakukan oleh dosen pengampu.

\section{Conclusion}

Setelah proses feedback dilakukan, langkah selanjutnya adalah pemberian kesimpulan dan rangkuman dari keseluruhan materi yang diajarkan. Pemberian tugas juga dilakukan disini, hal ini dilakukan untuk mengetes siswa sejauh mana mereka mengerti dan paham tentang materi yang diajarkan hari ini. 


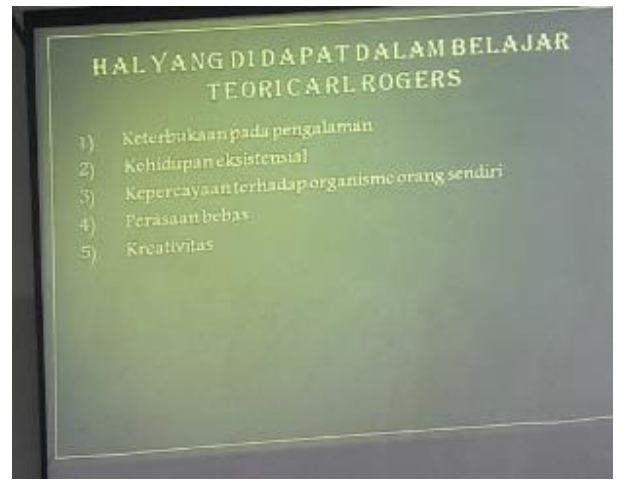

Gambar 7. Pemberian kesimpulan pada akhir pembelajaran

\section{Kemampuan Koneksi Matematis Mahasiswa}

Upaya untuk menjadikan matematika menjadi lebih bermakna bagi yang mempelajarinya dan untuk mendorong cara berfikir matematis dalam disiplin ilmu lain, telah lama direkomendasikan oleh The National Committee on Mathematics Requirements, yaitu sejak tahun 1923. Sedangkan pada tahun 1940, The Commission on The Secondary School Curriculum of the Progressive Education Assosiation, menekankan pentingnya suatu kurikulum yang terkoneksi (Coxford, 1995). Dalam kurikulum 2004, koneksi matematika tidak distandarkan secara khusus, namun penekanan terhadap pentingnya pembelajaran matematika yang lebih bermakna sudah dijabarkan dengan jelas.

Pandangan siswa terhadap matematika dapat diperluas melalui eksplorasi terhadap keterkaitan di antara ide-ide matematika, sehingga siswa memandang matematika sebagai suatu kesatuan yang menyeluruh dan bukan sebagai kumpulan topik yang tidak saling berkaitan. Siswa harus mendapat kesempatan untuk mengamati interaksi antara matematika dengan mata pelajaran lain dan kehidupan sehari-hari (everyday society).

Bruner (1987) menyatakan dalam matematika setiap konsep berkaitan dengan konsep yang lain. Begitupula dengan yang lainnya, misalnya dalil dan dalil, antara teori dan teori, antara topik dengan topik, ataupun antara cabang matematika dengan cabang matematika lain. Oleh karena itu agar siswa lebih berhasil dalam belajar matematika, maka harus banyak diberikan kesempatan untuk melihat keterkaitan-keterkaitan itu.

Pembelajaran matematika mengikuti metode spiral. Artinya dalam memperkenalkan suatu konsep atau bahan yang masih baru perlu memperhatikan konsep atau bahan yang telah dipelajari siswa sebelumnya. Bahan yang baru selalu dikaitkan dengan bahan yang baru dipelajari, dan sekaligus untuk mengingatkannya kembali.

Kemampuan koneksi matematis dapat terlihat didasarkan dari indikator-indikatornya, yaitu:

Mengenali representasi ekuivalen dari konsep yang sama

Aspek mathematical process dari koneski matematika meliputi : representasi, aplikasi, problem solving dan reasoning. Empat kategori aktifitas ini akan terus berlangsung selama seseorang mempelajari matematika. Agar siswa dapat memahami konsep secara mendalam, mereka harus membuat koneksi diantara representasi. Aktifitas aplikasi, problem solving, dan 
reasoning, membutuhkan berbagai pendekatan matematika, sehingga siswa dapat menemukan koneksi. Sebagai contoh untuk mencari turunan menggunakan defenisi fungsi, siswa harus mengaplikasikan limit dan komposisi fungsi. Komposisi fungsi dengan polinom berderajat besar melibatkan ekspansi binomial, yang koofisiensinya dapat diperoleh melalui perhitungan kombinatorik. Aktifitas program solving seperti pencarian nilai optimum,melibatkan pemodelan, representasi aljabar atau kalkulus. Pembuktian rumus-rumus turunan merupakan kegiatan reasoning yang melibatkan ide-ide matematik.

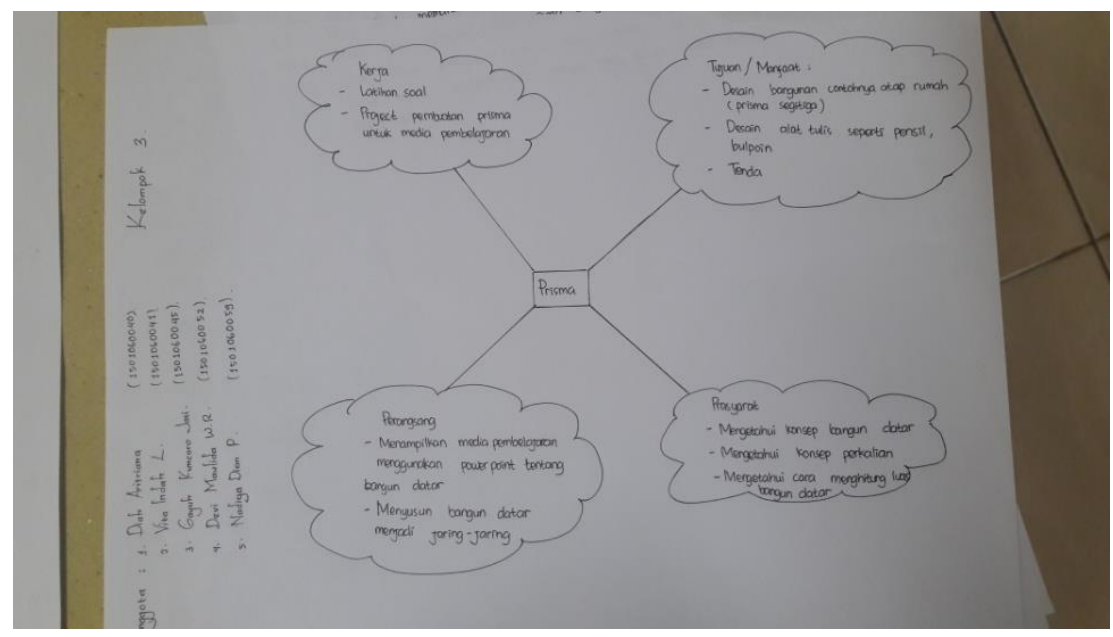

Gambar 8. Representasi dari Konsep Prisma

Mengenali hubungan prosedur matematika suatu representasi ke prosedur representasi yang ekuivalen

Pada pembelajaran Teori Belajar dan Pembelajaran, mahasiswa diminta untuk memahami teori belajar yang ada, dan dijadikan dasar untuk pengaplikasian konsep seperti model pembelajaran, metode pembelajaran, ataupun konsep pemelajaran lainnya. Di samping itu, pada pembelajaran ini, mahasiswa juga harus dapat mengkoneksikan konsep yang ada ke dalam pembelajaran matematika. Pada gambar di bawah ini mahasiswa mengkoneksikan konsep jenis belajar dan dapat mengidentifikasi jenis-jenis belajar mahasiswa saat belajar matematika. Hal ini sesuai dengan indicator kemampuan koneksi matematika yaitu mengenali hubungan prosedur matematika suatu representasi ke prosedur representasi yang ekuivalen.

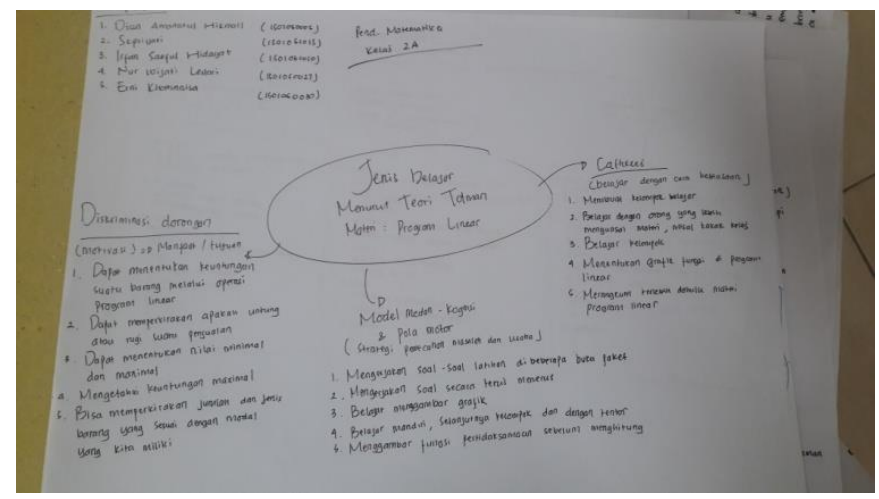

Gambar 9. Mengenal hubungan antara diskriminasi, model medan, dan cathexix pada materi Program Linear 
Menggunakan dan menilai keterkaitan antar topik matematika dan keterkaitan diluar matematika

Pada hal ini, mahasiswa mampu untuk mengaitkan konsep teori belajar yang ada ke dalam konsep pembelajaran matematika dan di luar matematika. Gambar di bawah ini menjelaskan bahwa mahasiswa mengkoneksikan Teori Sibernetik dan Teori Humanistik. Kedua teori tersebut dikoneksikan berdasarkan pembelajaran Geometri Ruang. Disini Nampak bahwa mahasiswa dapat mengaitkan antar teori sibernetik dengan teori humanistic. Teori sibernetik adalah sebuah teori yang menjelaskan bahwa belajar adalah pengolahan informasi, bagaimana mahasiswa dapat mengelola informasi yang ada ke dalam belajar geometri ruang, khususnya adalah luas bidang iris. Selanjutnya pada teori humanistic bagaimana seorang manusia dapat belajar dengan gaya belajarnya masing-masing.

Pada belajar geometri ruang mahasiswa mempunyai gaya/ tipe belajar masing-masing. Khusus pada belajar luas bidang iris mereka memiliki karakteristik sendiri-sendiri untuk mempelajari luas bidang iris. Kedua teori belajar tersebut dapat dikoneksikan dalam belajar geometri ruang, yang dalam hal ini geometri ruang adalah konsep di luar teori belajar yang ada. Akan tetapi mahasiswa dapat mampu mencari intisari dari kedua teori belajar tersebut dan dikoneksikan untuk mengetahui kaitannya dalam belajar geometri ruang.

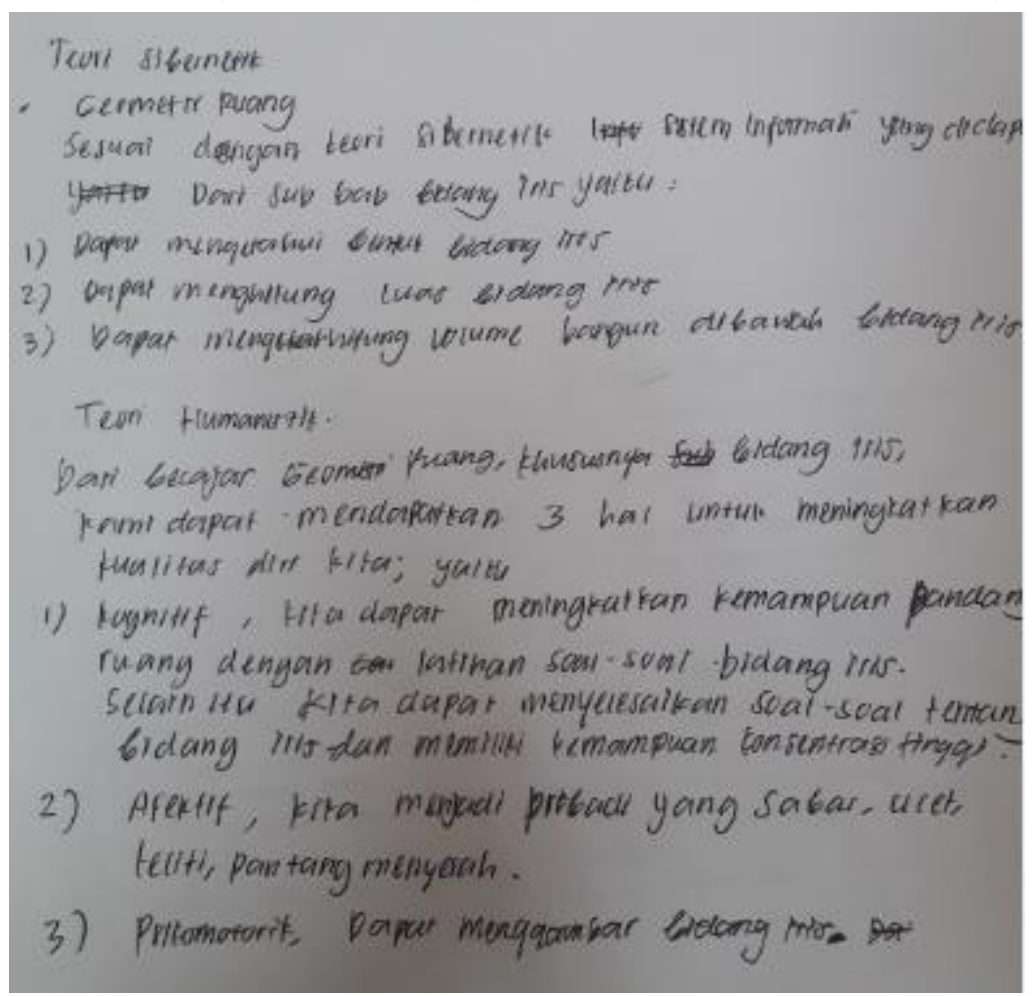

Gambar 10. Mendisusikan hubungan antara teori Sibernetik dengan Teori Humanistik Pada materi Geometri Ruang

\section{Menggunakan matematika dalam kehidupan sehari-hari}

Pada indicator kemampuan koneksi matematis yang terakhir adalah mahasiswa dapat mengkoneksikan konsep teori belajar ke dalam kehidupan sehari-hari. Seperti yang telah disajikan sebelumnya teori belajar adalah suatu dasar atau landasan konsep untuk 
menciptakan sebuah model atau metode pembelajaran di kelas. Akan tetapi model atau metode pembelajaran yang ada bisa saja untuk menumbuhkan karakter siswa di samping untuk mentransfer konsep pembelajaran. Karakter siswa bisa saja digunakan dalam pembelajaran di kelas, bisa pula untuk digunakan dalam kehidupan sehari-hari di rumah.

Seperti halnya dalam teori Bandura, siswa mendapatkan konsep berupa guru adalah contoh dalam pembelajaran. Siswa mendapatkan role model dari gurunya. Oleh karena itu, sebagai guru harus dapat memberikan contoh yang baik kepada siswa. Di dalam pembelajaran di kelas, contoh dapat ditirukan oleh siswa dari gurunya, sedangkan di rumah atau masyarakat contoh dapat diberikan dari orang tua ataupun dari lingkungan sekitar.

Oleh karena itu teori Bandura dapat pula diartikan sebagai sebuah teori yang memberikan contoh yang baik dari orang tua ataupun orang yang bisa memberikan pengaruh kepada anakanak. Seperti pada contoh di bawah ini, pada teori Vygotsky dimana guru dapat memberikan arahan dan bantuan kepada siswa yang mengalami kesulitan di kelas. Ataupun bagaimana guru dapat memberikan strategi di kelas manakala ditemukan kondisi kelas yang tidak aktif.

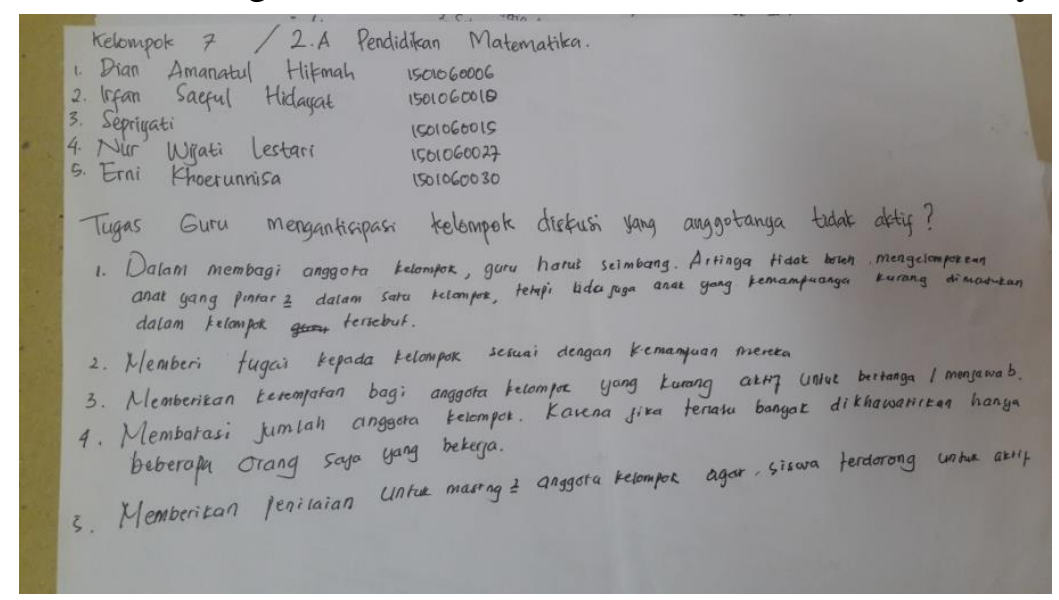

Gambar 11. Keterkaitan antar topic teori belajar dengan diskusi pembelajaran

\section{SIMPULAN}

Pemberian Example and non-Example Learning Model pada pembelajaran Teori Belajar dan Pembelajaran dapat meningkatkan wawasan mahasiswa dalam mendalami konsep teori belajar yang ada. Di samping itu pula, kemampuan koneksi mahasiswa dapat terlihat melalui tugas yang ada. Sedangkan, perkembengan dunia pendidikan terus berlangsung sejalan dengan tuntutan hidup manusia untuk menjawab perkembangan ilmu pengetahuan dan teknologi yang semakin hari semakin maju dan kompleks. Dunia pendidikan juga dituntut untuk peka terhadap perubahan dan perkembangan sekecil apa pun dalam dunia ilmu pengetahuan dan teknologi. Dalam konteks ini peran dosen tidaklah kecil. Dosen atau guru sebagai ujung tombak pelaksana pendidikan terdepan dituntut untuk terus mengembangkan pengetahuan, kemampuan serta keterampilannya.

\section{DAFTAR RUJUKAN}

Buehl, C. 1996. Example and non-example teaching and learning for students intelligence in classroom. Oklahoma: New Light Published 
194 Wanda Nugroho Yanuarto, Eka Setyaningsih

Budiningsih. 2005. Discovery learning sebagai pemecahan masalah pendidikan Indonesia. Bandung : Bineka Cipta Utama

Creswell, J. W. 2012. Educational Research. Boston: Pearson Education.

Daryanto. 2012. Media Pembelajaran. Bandung: Satu Nusa.

Emetembun. 1986. Penemuan sebagai Discovery learning dalam belajar. Yogyakarta: Media Raya

Fraenkel, R. J., \& Wallen, E. N. 2010. How To Design And Evaluate Research in Education. Boston: Mc Graw Hill

Hamalik, O. 2009. Curiculum guiding commite of the winconsin cooperative educational program.

Hamzah. 2003. Teori belajar dan pembelajaran sebagai jiwa pendidikan. Jakarta: Media Utama

Joolingen, W.R. van, \& Jong, T. de. 1997. An extended dual search space model of scientific discovery learning. Instructional Science, 25, 307-346.

Miles \& Huberman. 1992. Penelitian kualitatif dalam pendidikan. Jakarta: Cipta Reka Utama

Musfiqon. 2012. Pengembangan Media dan Sumber Pembelajaran. Jakarta: PT. Prestasi Pustakarya.

National Council of Teachers of Mathematics. 1989. How to connecting concepts and real situation in students' life. New York: Routledge

dan Penilaian. Bandung: CV Wacana Prima.

Sudjana, N., Rivai, A. 2010. Media Pengajaran. Bandung: Sinar Baru Algensindo.

Sumarmo, U. 2005. Suatu Alternatif Pengajaran untuk Meningkatkan Kemampuan Koneksi matematika pada Guru dan Siswa SMP. Laporan penelitian IKIP Bandung.

Bandung: Tidak diterbitkan.

Sugiyono. 2012. Memahami Penelitian Kualitatif. Bandung: Alfabeta.

Susilana, R., Riyana, C. 2009. Media Pembelajaran Hakikat, Pengembangan, Pemanfaatan Sugiyono. 2012. Metode Penelitian Pendidikan. Bandung: Alfabeta

Uno. 2006. Instructional Learning as good goals in education. New York: Routledge 